\title{
Potential Role of Bcl-2 and Bax mRNA and Protein Expression in Chronic Hepatitis Type B and C: A Clinicopathologic Study
}

Athanassios C. Tsamandas, M.D., Konstantinos Thomopoulos, M.D., Vassiliki Zolota, M.D., Theodore Kourelis, M.D., Theodore Karatzas, M.D., Panagiota Ravazoula, M.D., Konstantinos Tepetes, M.D., Theodore Petsas, M.D., Dionissios Karavias, M.D., Chrisoula Karatza, M.D., Dionysis S. Bonikos, M.D., Charalambos Gogos, M.D.

Departments of Pathology (ACT, VZ, PR, DSB), Internal Medicine (CG, KTh, TKo, CK), Surgery (TKa, KTe, DK), and Radiology (TP), University of Patras School of Medicine, Patras, Greece

Bcl-2 oncoprotein regulates programmed cell death by providing a survival advantage to rapidly proliferating cells, and bax protein promotes apoptosis by enchanting cell susceptibility to apoptotic stimuli. In this study, we assessed the expression of bcl-2 and bax in liver biopsies from patients with chronic hepatitis (CH) Type B (HBV) and C (HCV). The study comprised 65 liver biopsies from 65 patients with HBV $(n=37)$ and HCV $(n=28)$ and 10 normal liver biopsies as controls. The HAI score ranged from $3 / 18-13 / 18$, and the fibrosis Stage, from 1-6 (7 $\mathrm{HBV} / 10 \mathrm{HCV}$ ). Pathologic examination included the following: (1) immunohistochemical stains in paraffin sections for bcl-2 and bax protein expression, (2) Western blot analysis (bcl-2 and bax protein levels evaluation), (3) ISH (detection of bcl-2 and bax mRNA), and (4) ISH (TUNEL-ABI [apoptotic body index]). In $\mathrm{CH}$ cases, both bcl-2 and bax protein and mRNA were detected in portal and intralobular lymphocytes and in cholangiolar epithelial cells in interface areas and fibrous bands. Bax protein and mRNA was expressed within hepatocytes and epithelial cells of interlobular ducts in portal tracts. Bcl-2 mRNA was present in periportal hepatocytes only in cases with Stage 5-6 fibrosis. Western blot analysis showed a decreased bcl-2 and an increased bax expression toward advanced fibrotic stages. In $\mathrm{CH}$ cases, $\mathrm{ABI}$ was reverse correlated with the per-

Copyright () 2003 by The United States and Canadian Academy of Pathology, Inc.

VOL. 16, NO. 12, P. 1273, 2003 Printed in the U.S.A

Date of acceptance: August 15, 2003.

Presented in part at the 88th Annual USCAP meeting, San Francisco, CA,

March 20-26, 1999 and published in abstract form: Modern Pathology

12(1): 168A, 1999

Address reprint requests to: Athanassios C. Tsamandas, M.D., Department of Pathology, University of Patras School of Medicine, 88 Agiou Demetriou str., Patras 26252 Greece; fax: 30610991810; e-mail tsamanda@otenet.gr.

DOI: 10.1097/01.MP.0000097367.56816.5E centage of bcl-2 expression and was correlated directly with the percentage of bax expression $(P<$ $.001)$. The results of this study suggest that in cases of chronic HBV or HCV infection, bax may be involved in the hepatocyte cycle regulation during infection, whereas its expression in intraportal bile duct epithelium implies that this protein enhances susceptibility of these particular cells to apoptosis. The increased bax expression and $\mathrm{ABI}$ in fibrosis Stages 1-5, imply that they are responsible for hepatocytes depletion through apoptosis, during progress of liver fibrosis and fibrous tissue accumulation, until cirrhosis is established. Bcl-2 mRNA expression in periportal hepatocytes only in Stages 5 and 6 suggests that this oncogene is involved in the late stages of progressive liver fibrosis and failure and furthermore that periportal hepatocytes are resistant to apoptosis. Bcl-2 expression, in cholangioles of interface area, suggests that this oncoprotein may be involved in growth regulation of these epithelial cells. Further research is warranted to specify the exact role of apoptosis and apoptotic genes involved in liver fibrosis process in cases of chronic HBV and HCV infection. This may lead to new strategies in the management of human liver disease to prevent the progression to chronic liver failure.

KEY WORDS: Apoptosis, Bax, Bcl-2, Bile duct, Chronic hepatitis, Immunohistochemistry, In situ hybridization, Liver, Liver fibrosis, Western blot.

Mod Pathol 2003;16(12):1273-1288

The relentless progression of many liver diseases results in end-stage liver failure, independently of the initial pathogenic mechanism. Progress of chronic liver failure is associated with depletion of hepatocytes along with liver fibrosis. The transition from liver growth and hypercellularity to cell deple- 
tion and atrophy raises the question as to which process is responsible for cell loss.

Cell homeostasis is the result of the balance between apoptosis, cell proliferation, and growth arrest. Apoptosis is a morphologically distinct, genedirected form of cell death that is characterized by cytoplasmic fragmentation and nuclear condensation and that contributes to both physiological and pathological processes $(1,2)$. In the liver, apoptosis and apoptosis-related proteins contribute to intrahepatic bile duct development; previous studies have demonstrated the expression of apoptosisrelated proteins in normal and diseased human liver, including instances of acute and of chronic hepatitis $(\mathrm{CH})(3-8)$.

One of the oncogenes that regulates apoptosis is bcl-2. It is located at chromosome 18q21, and its expression was first described in studies regarding $t$ chromosome translocation in B-cell lymphoma (9). Bcl-2 encodes a $26-\mathrm{kDa}$ protein that blocks programmed cell death without affecting cellular proliferation (10). It has emerged as a key regulator of apoptosis, because it can protect cells from death induced by a number of injuries including radiation, chemotherapy, or growth factor deprivation. Bcl-2 has been detected in the long-lived, selfrenewing populations of stem cells that line the basement membrane of several epithelia, including skin, colon, and prostate, but not in the terminally differentiated cells that are found at the surface of those epithelia, which are believed to die by apoptosis (11).

In the liver, bcl-2 presence has been reported in areas of cholangiolar proliferation and focally, in hepatocytes in patients with cirrhosis caused by hepatitis $C(5,6,7)$. Previously we have shown that bcl-2 protein is expressed in cholangiolar epithelial cells in cases of chronic, but not acute, lobular hepatitis Type B or C (8). In addition, bcl-2 expression was also shown in periportal hepatocytes of the bile duct-ligated rat, where it is believed to protect metaplastic hepatocytes from cholestasisinduced apoptotic death (12). Furthermore, in cases of hepatocellular carcinomas, previous studies have shown that bcl-2 mRNA is produced from tumor cells, whereas bcl-2 protein is not expressed, implying absence of a well-demonstrated posttranscriptional control of bcl-2 (13).

Bax protein is a homologue of bcl-2 that promotes apoptosis (14). Bax may bind to bcl-2, forming bax-bcl-2 heterodimers, or may bind to itself forming bax-bax homodimers (14). The ratio of bax to bcl-2 determines the susceptibility of a cell to apoptosis. Thus, in cells with bax overexpression, bax homodimers predominate, and the susceptibility of such cells to apoptotic stimuli is enhanced. Bax-bcl-2 heterodimers predominate in cells that overexpress bcl-2, and the susceptibility of these cells to apoptosis is reduced $(14,15)$. Bax mRNA appears to be present in a variety of tissues, including lung, stomach, kidney, and thymus, whereas bax protein has been detected by immunohistochemistry in mouse, rat, and human tissues (16, 17), including several malignant tumors, in which their expression has been related to tumor stage or to the response to adjuvant treatment $(18,19)$. In the normal rat liver, bax has been detected in hepatocytes and ductal epithelial cells $(16,17)$. Previous studies have shown that in the BDL rat model, bax is overexpressed from hepatocytes (12), whereas other reports have demonstrated that bax is expressed from ductular epithelial cells only late after $\mathrm{BDL}$, and this finding is related to cholangiolar absence through apoptosis (20).

This study investigates bcl-2 and bax mRNA and protein expression in cases of $\mathrm{CH}$ Type $\mathrm{B}$ and $\mathrm{C}$ and attempts to determine their contribution to the development of liver fibrosis and impairment of liver function.

\section{PATIENTS AND METHODS}

\section{Patients}

The study comprised 50 serial needle liver biopsies that were obtained from an equal number of patients with CH Type B $(n=29)$ and C $(n=21)$, for therapeutic purposes, as well as 15 serial wedge biopsies of nonneoplastic liver obtained from an equal number of patients with $\mathrm{CH}$ Type $\mathrm{B}(n=8)$ and $\mathrm{C}(n=7)$, during hepatectomy for hepatocellular carcinoma. In all 65 cases, the diagnosis of $\mathrm{CH}$ was made according to standard criteria (21). All patients with chronic HBV infection were $\operatorname{HbeAg}(-)$, anti-HbeAb $(+)$, and $\operatorname{HBVDNA}(+)$, whereas all patients with chronic HCV infection were $\operatorname{HCVRNA}(+)$. For the purposes of the study, all the clinical and biochemical features pertaining to these patients at the time of the diagnosis were obtained by review of clinical records. For-control purposes, 10 wedge biopsies from normal liver parenchyma were used. These were obtained from 10 patients during operation for cholelithiasis, without coexisting choledocholithiasis. In the 15 cases from patients who underwent hepatectomy and in the 10 control cases, for each liver sample, a piece was kept frozen for Western blot analysis and the remaining was fixed in $10 \%$ neutral formalin. For each CH case, $1 \mathrm{H} \& \mathrm{E}, 1$ periodic acid-Schiff, 1 periodic acid-Schiff-D, 1 Pearl's, 1 reticulin, and 1 Masson's trichrome stain were available. All slides were reviewed in a blind fashion and without knowledge of the clinicolaboratory profile of the patient. In each biopsy, several histologic features were assessed, and finally the Hepatitis Activity Index (HAI) was applied and the architectural grade 
was recorded (22). Thus, in the 65 biopsies with $\mathrm{CH}$ included in the study, the HAI score ranged from $3 / 18-13 / 18$, and the architectural stage, from 1 to 6 (7 HBV/10 HCV). Table 1 lists all the clinicopathologic data.

\section{Immunohistochemistry for the Detection of Bcl-2} and Bax Proteins

The detection of cells that express bcl-2 and bax proteins relied on immunohistochemistry based on a streptavidin biotin peroxidase method (Biogenex, San Ramon, CA) as described elsewhere $(8,18,19)$. Four-micrometer-thick paraffin sections were used, and primary antibodies included the following: monoclonal antibody to bcl-2 (DAKO; at a dilution of 1:40) and polyclonal antibody to bax (Santa Cruz; at a dilution of 1:1000). All incubations were performed for 30 minutes at room temperature. Diaminobenzidine (Sigma Fast 3,3'-diaminobenzidine tablets, D-4293; Sigma, St. Louis, MO) or 3-amino9-ethylcarbazole (AEC, K3461, DAKO) were used as chromogens. Cytoplasmic staining for bcl-2 and bax was considered a positive result. For positivecontrol purposes, the same staining procedure (for bcl-2 or bax) was performed on paraffin sections from human tonsils. For negative-control purposes, the same streptavidin-biotin technique was used on tissue sections in which $1 \%$ BSA in PBS substituted the primary antibody.

\section{Immunohistochemistry for CK19, Leukocyte} Common Antigen, Hepatocyte Antigen

The same streptavidin-biotin method was used to stain sections for cytokeratin 19 (CK19; Novocastra;

TABLE 1. Clinical and Histologic Characteristics of Patients with $\mathrm{CH}(\mathrm{N}=65)$

\begin{tabular}{lcc}
\hline & $\begin{array}{c}\text { HBV } \\
\mathrm{n}=37\end{array}$ & $\begin{array}{c}\mathrm{HCV} \\
\mathrm{n}=28\end{array}$ \\
\hline Sex & $24 \mathrm{M} ; 13 \mathrm{~F}$ & $21 \mathrm{M} ; \mathrm{F}$ \\
Age (yr) & $53(30-70)$ & $52(25-60)$ \\
Mean (range) & $3(1-4)$ & $2(1-4)$ \\
HAI score, mean (range) & $0(0-1)$ & $0(0-1)$ \\
Category A & $2(1-4)$ & $2(1-4)$ \\
Category B & $3(1-4)$ & $3(1-4)$ \\
Category C & $9(3-13)$ & $8(3-13)$ \\
Category D & & \\
Total score & $9^{\mathrm{a}}$ & $4^{\mathrm{b}}$ \\
Stage (\# of cases) & $5^{\mathrm{c}}$ & $3^{\mathrm{d}}$ \\
1 & $6^{\mathrm{e}}$ & $3^{\mathrm{f}}$ \\
2 & $6^{\mathrm{g}}$ & $4^{\mathrm{h}}$ \\
3 & $4^{\mathrm{i}}$ & $4^{\mathrm{j}}$ \\
4 & $7^{\mathrm{k}}$ & $10^{\mathrm{l}}$ \\
5 & & $92(71-98)$ \\
6 & $93(78-105)$ & $78(70-95)$ \\
Laboratory values mean (range) & $89(71-98)$ & \\
AST & & \\
ALT & & \\
\hline
\end{tabular}

CH: chronic hepatitis; HBV: hepatitis B, HCV: hepatitis C, HAI: hepatitis activity index, ${ }^{a}, \mathrm{~b}, \mathrm{~d}, \mathrm{e}, \mathrm{f}, \mathrm{h}, \mathrm{i}, \mathrm{j}, \mathrm{k}: \mathrm{l}$ patient had co-existent hepatocellular carcinoma, ${ }^{\mathrm{c}, g, \mathrm{l}}: 2$ patients had co-existent hepatocellular carcinoma. in a dilution of 1:100), leukocyte common antigen (Biogenex; ready to use) and hepatocyte paraffin antigen (DAKO; in a dilution of 1:100). These stains were performed for morphometric analysis purposes, as described below (see Morphometric Analysis in this article).

\section{Western Blot Analysis of Bcl-2 and Bax Proteins}

For Western blot purposes, we used a method that has been described in detail elsewhere (23). Briefly, liver tissue was homogenized using a glassglass homogenizer, in $50 \mathrm{~mm}$ Tris- $\mathrm{HCl}, \mathrm{pH}$ 7.4, containing $3.4 \mathrm{M} \mathrm{NaCl}, 1 \mathrm{~mm}$ phenylmethylsulfonyl fluoride (PMSF), 4 mm EDTA, 2 mm $N$-ethylmaleimide (NEM), and $1 \mathrm{mg} / \mathrm{mL}$ aprotinin. The homogenates were centrifuged at $12,000 \times g$ for 20 minutes at $4^{\circ}$ C. Final pellet was resuspended in $50 \mathrm{~mm}$ Tris, $\mathrm{pH}$ 7.4, containing 4 mм EDTA, 1 mM PMSF, and $2 \mathrm{~mm}$ NEM, and the total protein concentration was determined using the Bradford method (24). Equal amounts of total protein were loaded on $17 \%$ polyacrylamide gels, analyzed, and transferred to Immobilon P membranes. Blocking was performed by incubating the PVDF membranes with $5 \%(\mathrm{w} / \mathrm{v})$ nonfat dry milk in Tris-buffered saline (TBS), $\mathrm{pH}$ 7.4, for 1 hour at room temperature and under continuous agitation. The membranes were then incubated with anti-bcl-2 (1:400, DAKO) or anti-bax (1:200; Santa Cruz) in 5\% (w/v) nonfat dry milk in TBS and $0.05 \%$ Tween-20 (TBS-T) for 3 hours at room temperature under continuous agitation and thereafter, with horseradish peroxidase-conjugated goat anti-rabbit IgG at a dilution of 1:2500 in 3\% (w/v) nonfat dry milk in TBS-T for 1.5 hour at room temperature under continuous agitation. Detection of immunoreactive bands was performed by diaminobenzidine (3,3'-diaminobenzidine; Sigma). The antibodies used did not show any cross-reactivity (data not shown). For positive-control purposes, we used fresh human tonsils. Gel pictures were digitized, and the protein levels that corresponded to each immunoreactive band were quantitated using the ImagePC image analysis software (Scion Corporation, Frederick, MD).

\section{In Situ Hybridization for Bcl-2 and Bax mRNA Detection}

For the detection of bcl-2 and bax mRNA, a standard nonradioactive in situ hybridization (ISH) method, using the Hybridization/Detection Complete System (MBI), was performed on paraffin sections as previously described $(13,18)$. Four- $\mu \mathrm{m}-$ thick sections were cut for ISH, taking care to prevent RNAse contamination. The method was performed according to the manufacturer's instructions. Briefly, $4-\mu \mathrm{m}$-thick sections were dewaxed, 
hydrated, incubated with $1 \times$ proteinase $\mathrm{K}$ solution for 30 minutes at $37^{\circ} \mathrm{C}$, dehydrated, and dried at $37^{\circ}$ $\mathrm{C}$ for 5 minutes. Thereafter, sections were incubated with digoxigenin (DIG)-labeled riboprobe (for bcl-2 and bax in a 10-fold dilution in hybridization solution; MBI) under a glass coverslip at $70^{\circ}$ $\mathrm{C}$ for 10 minutes (RNA secondary structure denaturation) and subsequently, at $37^{\circ} \mathrm{C}$ for 4 hours to complete hybridization. Subsequently, 1 drop of Rnase $(15 \mu \mathrm{g} / \mathrm{mL})$ was placed on the sections, and slides were incubated at $37^{\circ} \mathrm{C}$ for 30 minutes. Thereafter, the specific protocol (Hybridization/ Detection Complete System [MBI]) was performed according to the manufacturer's instructions, and BCIP/NBIT (DAKO) was used as a chromogen. Slides were counterstained with Nuclear Fast Red (DAKO). Cytoplasmic staining for bcl-2 and bax was considered a positive result. For positive control tissues, we used paraffin sections from human tonsils. To confirm that the positive stain was specific, the slides were processed in an identical way and hybridized with probes that are known to be complementary to sequences in the test sections (human genomic DNA probes; positive control probes). These probes (biotinylated oligonucleotide probes) were similar in length and GC content to bcl-2 and bax probe. For negative-control purposes, the slides were processed in the same way but were hybridized with heterologous probes. The latter were not complementary to any sequence in the test tissues. These negative-control probes were similar in length and in GC content to bcl-2 and bax probe. The positive- and negative-control probes were provided by MBI.

\section{In Situ Labeling of Fragmented DNA for the Detection of Apoptotic Cells}

On $4-\mu \mathrm{m}$ paraffin sections, a standard TUNEL method was employed to detect the fragmented nuclear DNA associated with apoptosis. For this purpose, the In Situ Cell Death Detection Kit, POD (Roche) was used as previously described $(8,18)$. After standard deparaffinization, hydration, incubation with proteinase $\mathrm{K}$, and blocking of endogenous peroxidase, tissue sections ( $4 \mu \mathrm{m}$ thick) were incubated as follows: (1) with TdT (terminal deoxynucleotidyl transferase) and digoxigenin-dUTP (TUNEL reaction mixture) at $37^{\circ} \mathrm{C}$ for 60 minutes and (2) with peroxidase converter anti-fluorescein antibody at $37^{\circ} \mathrm{C}$ for 30 minutes. Diaminobenzidine (Sigma Fast 3,3'-diaminobenzidine tablets, D-4293; Sigma) was used as the chromogen. For physiological positive controls, sections of rat small intestine were subjected to the same procedure. For negative controls, some slides were incubated with label solution that did not contain TdT.
Double Immunostains

Bcl-2 $m R N A+$ bax protein and bax $m R N A+b c l-2$ protein

After ISH for bcl-2 or bax mRNA was completed, and before counterstaining with Nuclear Fast Red, sections were rinsed with TBS for 30 minutes and were incubated with anti-bax or anti-bcl-2 antibody, as described earlier in this article. Subsequently, a standard streptavidin biotin method (MultiLink; Biogenex) was applied, and AEC was used as chromogen. The sections were not counterstained.

\section{Bax and bcl-2 protein}

After immunohistochemistry for bax was completed and 3,3'-diaminobenzidine was applied, and before counterstaining with Harris hematoxylin, slides were rinsed in TBS for 30 minutes. Subsequently, incubation with anti-bcl-2 antibody was done. Thereafter, a standard alkaline phosphatase method (Kwik Kit, Shandon, PA) was applied, according to manufacturer's instructions, and Fast Red was used as a chromogen. Sections were counterstained with Harris hematoxylin.

\section{Bcl-2 and Bax proteins and HBS and HBc antigens}

After immunohistochemistry for bcl-2 or bax protein was completed and 3,3'-diaminobenzidine was applied, and before counterstaining with Harris hematoxylin, slides were rinsed in TBS for 30 minutes. Subsequently incubation with anti-HBS and HBc antigen (both Biogenex, ready to use) was done. Thereafter a standard alkaline phosphatase method (Kwik Kit, Shandon, PA) was applied, according to the manufacturer's instructions, and Fast Red was used as chromogen. Sections were counterstained with Harris hematoxylin.

\section{TUNEL and bcl-2 protein, TUNEL and bax protein}

After TUNEL method was completed and 3,3'diaminobenzidine was applied, and before counterstaining with Harris hematoxylin, sections were rinsed with TBS for 30 minutes and then were incubated with the primary antibody (bcl-2 or bax), and a standard alkaline phosphatase method (Kwik Kit) was applied, according to manufacturer's instructions, and Fast Red was used as chromogen. Sections were counterstained with Harris hematoxylin.

\section{Morphometric Analysis}

For the purposes of quantitative analysis of the percentage of the cells that displayed (1) positive immunohistochemical stain for bcl-2 and bax proteins (cytoplasmic staining), (2) positive ISH stain for bcl-2 and bax mRNA (granular cytoplasmic 
staining), and (3) positive TUNEL reaction for fragmented DNA (nuclear staining), we used an image analysis method that has been described in detail elsewhere $(25,26)$. For this purpose, we used a color camera (KY-F55MD; Olympus, Tokyo, Japan) mounted on an Olympus BX 40F (Olympus). From these, color images were digitized to a Pentium III $450-\mathrm{MHz}$ computer. Each time, before measurements of the images were taken, we standardized the contrast and brightness and calibrated the measurement system with appropriate slides. The latter included the slides that we used as positive controls in the immunohistochemical and ISH stains, as were described above. We excluded the edges of the sections from the evaluation. Classification of the different types of bile ducts that were included in the specimens was performed according to a method described elsewhere (27). According to this, the needle and wedge surgical specimens contained interlobular bile ducts and cholangioles, which were defined as follows: interlobular bile ducts have an internal diameter of $<100 \mu \mathrm{m}$ and are composed of cuboidal epithelial cells; they do not have periductal fibrous walls and are associated with a hepatic artery and portal vein. Cholangioles are located adjacent to the hepatocytes in the interface areas of the portal tracts. The length measurement tool (Image-Pro Plus software program; Media Cybernetics, Silver Spring, MD) was used to evaluate (1) the diameters of interlobular ducts and cholangioles in given sections stained with CK19, (2) the size of lymphocytes in given sections stained with leukocyte common antigen, and (3) the size of hepatocytes in given sections stained with hepatocyte paraffin antigen (described earlier in this article). For quantitation of immunostaining intensities, we measured the inverse mean density (25) based on the RGB color parameter (26). The circle profile tool of Image-Pro Plus program (Media Cybernetics) was used for measurements of cytoplasmic bcl-2 and bax immunostaining, respectively. According to previous reports (25) in each case, 20 randomly selected color video images of $512 \times 512$ pixels with a resolution of $0.4348 \mu \mathrm{m}$ were done. These represented 6800 measurements for each protein that was analyzed in each biopsy. Measurements were done separately for hepatocytes, lymphocytes, and interlobular bile ducts and proliferating cholangioles and in the interface area and fibrous bands. For each set of measurements, a curve was made according to immunostaining intensity. The units arbitrarily ranged from 0 (intensity absent) to 230 (top intensity). In each case, the percentage of TUNEL $(+)$ cells gave the apoptotic body index (ABI) for each case. All the measurements were done independently by 2 authors (ACT, $\mathrm{PR}$ ) who were blinded to the clinical profile of the patients. When major discrepancies occurred, a consensus score was reached.

Any coexpression of bcl-2 and bax (proteinprotein or mRNA-protein) and TUNEL-bcl-2 protein or TUNEL-bax protein was recorded as present $(+)$ or absent $(-)$.

\section{Statistical Analysis}

Results were reported as mean $\pm \mathrm{SD}$. Intergroup comparisons regarding correlation of staining results in $\mathrm{CH}$ cases were performed using one-way analysis of variance (ANOVA). When the equalvariance test or normality test failed, the KruskalWallis nonparametric test was applied. To address the problem of multiple comparisons, these tests (ANOVA and Kruskal-Wallis) were followed by a post hoc Neuman-Keuls test. The Spearman rank correlation test was used to examine the possible associations between the staining results for bcl-2, bax, and TUNEL on the one hand and the transaminase values, HAI grade, and stage on the other. Spearman rank correlation was also used to detect any relationships between bcl-2, bax, and ABI. Data were analyzed using the SPSS package (SPSS). Significance was defined as $P<.05$.

\section{RESULTS}

\section{Bcl-2 Expression}

Table 2 summarizes the results for bcl-2 (protein and mRNA) expression, and Figure 1 shows the results of Western blot analysis for bcl-2 protein expression. Immunohistochemistry for bcl-2 protein and ISH for bcl-2 mRNA displayed different staining patterns. In normal control cases, bcl-2 protein was detected in scattered lymphocytes if these were present (Fig. 2A). Hepatocytes and ductular epithelial cells were negative. These results are in agreement with those of a previous study (8). In cases with $\mathrm{CH}$, bcl-2 was expressed within lymphocytes in portal tracts, lobules, and bands of fibrous tissue and in cholangioles of interface area (Fig. 2B-G, J, and K). In addition, bcl-2 mRNA was expressed within hepatocytes near the portal tracts or fibrous tissue bands in cases of $\mathrm{CH}$ Stage 5 and 6 (incomplete or established cirrhosis; Fig. 2L). $\mathrm{CH}$ cases with Fibrosis Stage $\leq 4$ did not show any hepatocytic bcl-2 mRNA expression. Interlobular bile ducts of portal tracts were negative for bcl-2 protein or mRNA (Fig. 2C-D). When the negative control (sense) probe was used in ISH, no staining was present. Statistical analysis revealed strong correlation between lymphocytic bcl-2 expression and HAI Categories A, C, and D ( $r=0.720,0.718$, and 0.741 , respectively; $P<.001$ in all cases). In addition, direct correlation was recorded between lym- 


\begin{tabular}{|c|c|c|c|c|}
\hline \multirow{2}{*}{ Distribution } & \multicolumn{2}{|c|}{ Bcl-2 Protein } & \multicolumn{2}{|c|}{ Bcl-2 mRNA } \\
\hline & Controls & $\mathrm{CH}$ & Controls & $\mathrm{CH}$ \\
\hline \multicolumn{5}{|l|}{ Portal tracts } \\
\hline Lymphocytes & NP & $0.49 \pm 0.02$ & NP & $0.47 \pm 0.03$ \\
\hline Interlobular ducts & 0 & 0 & 0 & 0 \\
\hline \multicolumn{5}{|l|}{ Interface area } \\
\hline Cholangioles & NP & $0.32 \pm 0.05$ & NP & $0.33 \pm 0.11$ \\
\hline Lymphocytes & $0.12 \pm 0.02^{\mathrm{a}}$ & $0.45 \pm 0.3^{\mathrm{a}}$ & $0.16 \pm 0.04^{\mathrm{c}}$ & $0.46 \pm 0.03^{\mathrm{c}}$ \\
\hline \multicolumn{5}{|l|}{ Lobules } \\
\hline Hepatocytes & 0 & 0 & 0 & $0.13 \pm 0.07^{*}$ \\
\hline Kupffer cells & 0 & 0 & 0 & 0 \\
\hline Lymphocytes & $0.1 \pm 0.01^{\mathrm{b}}$ & $0.44 \pm 0.2^{\mathrm{b}}$ & $0.12 \pm 0.03^{\mathrm{d}}$ & $0.47 \pm 0.1^{\mathrm{d}}$ \\
\hline Fibrous bands & NP & & NP & \\
\hline Lymphocytes & & $0.33 \pm 0.1$ & & $0.31 \pm 0.02$ \\
\hline Cholangioles & & $0.31 \pm 0.04$ & & $0.34 \pm 0.3$ \\
\hline
\end{tabular}

Values are mean \pm SD. NP: not present, $\mathrm{CH}$ : chronic hepatitis.

Differences significant at $\mathrm{p}<0.01$ in data with matching letter a, b, c, d..

* Only in cases with fibrosis stage 5 and 6 ( 11 instances of HBV and 14 cases of HCV)

phocytic bcl-2 expression and transaminase values $(r=0.446, P<.05$ for ALT and $r=0.481, P<.05$ for AST). Cholangiolar bcl-2 expression was reversibly correlated with the degree of fibrosis for Stages 1-5 ( $r=-0.612, P<.01)$. No correlation was found between bcl-2 expression and total HAI score or cause of hepatitis.

Figure 1 shows the protein levels for the gene bcl-2 after Western blotting technique was applied. In livers from normal controls, no immunoreactive bands could be detected for bcl-2. Bcl-2 protein levels decreased with advance in fibrotic stages $(P<.01)$.

\section{Bax Expression}

Table 3 exhibits the results of immunohistochemistry and ISH for bax protein and bax mRNA expression, respectively, and Figure 3 demonstrates the results for Western blot analysis for bax protein levels. As Table 3 shows, in control cases, bax protein and bax mRNA were detected in hepatocytes and ductal epithelial cells, and in rare lymphocytes, if these were present. Our results are in agreement with previous studies $(16,17)$. In cases with $\mathrm{CH}$, bax oncoprotein and mRNA displayed a similar pattern. They were expressed within hepatocytes, epithelial cells of interlobular bile ducts, and lymphocytes and in small (hyperplastic) cholangiolar epithelial cells (Fig. 4A-B). The staining pattern was cytoplasmic and membranous for bax protein and cytoplasmic for bax mRNA (Fig. 4C-D). In ISH, when we used the negative control (sense) probe, no staining was present. These results for bax mRNA expression, combined with those of bcl-2 mRNA presence, confirm that bcl-2, bax, or both are actively produced within hepatocytes or within ductal or ductular epithelial cells. Statistical analysis showed that bax expression within hepatocytes and ductular epithelial cells was lower in controls when com- pared with in $\mathrm{CH}$ cases $(P<.01)$. Lymphocytic bax expression was directly correlated with HAI Categories $\mathrm{A}, \mathrm{C}$, and $\mathrm{D}(r=0.732,0.711$, and 0.738 , respectively; $P<.001$ in all cases), whereas cholangiolar bax expression was correlated with HAI Categories $\mathrm{C}$ and $\mathrm{D}(r=0.684, P<.01)$. No correlation was found between bax expression and total HAI score or cause of hepatitis. Cholangiolar bax expression in fibrous bands was correlated directly with the degree of fibrosis only in Stages 1-5 ( $r=$ $0.64, P<.01)$. Finally, a significant direct correlation between bax expression and transaminases was recorded ( $r=0.467, P<.05$ for ALT and $r=$ $0.413, P<.05$ for AST).

Figure 3 shows the protein levels for the gene bax after Western-blotting technique was applied. Bax protein was detected in livers from normal controls and from patients with $\mathrm{CH}$, with significantly increased levels in the latter. In addition, bax protein levels increased with advance in fibrotic stage $(P<.01)$.

\section{Pattern of Staining for Apoptotic Cells}

All the results regarding ABI are shown in Table 4. Apoptotic cells were identified in the hepatocytes (Fig. 5A-D) and in lymphocytes, epithelial cells of interlobular bile ducts and cholangiolar epithelial cells within portal tracts, in the interface area and in the bands of connective tissue (Fig. 5B). Statistical analysis revealed that there was significant direct correlation between ABI and transaminase values ( $r$ $=0.4, P<.05$ for ALT and $r=0.41, P<.05$ for AST), HAI Category C, and Stages 1-5, but not Stage 6. In addition, a significant reverse correlation was detected between $\mathrm{ABI}$ and bcl-2 expression in $\mathrm{CH}$ cases (with Fibrosis Stage 1-5; Fig. 6), whereas a direct correlation between $\mathrm{ABI}$ and bax expression (for $\mathrm{CH}$ cases with Fibrosis Stage 1-5) was recorded (Figure 7). 

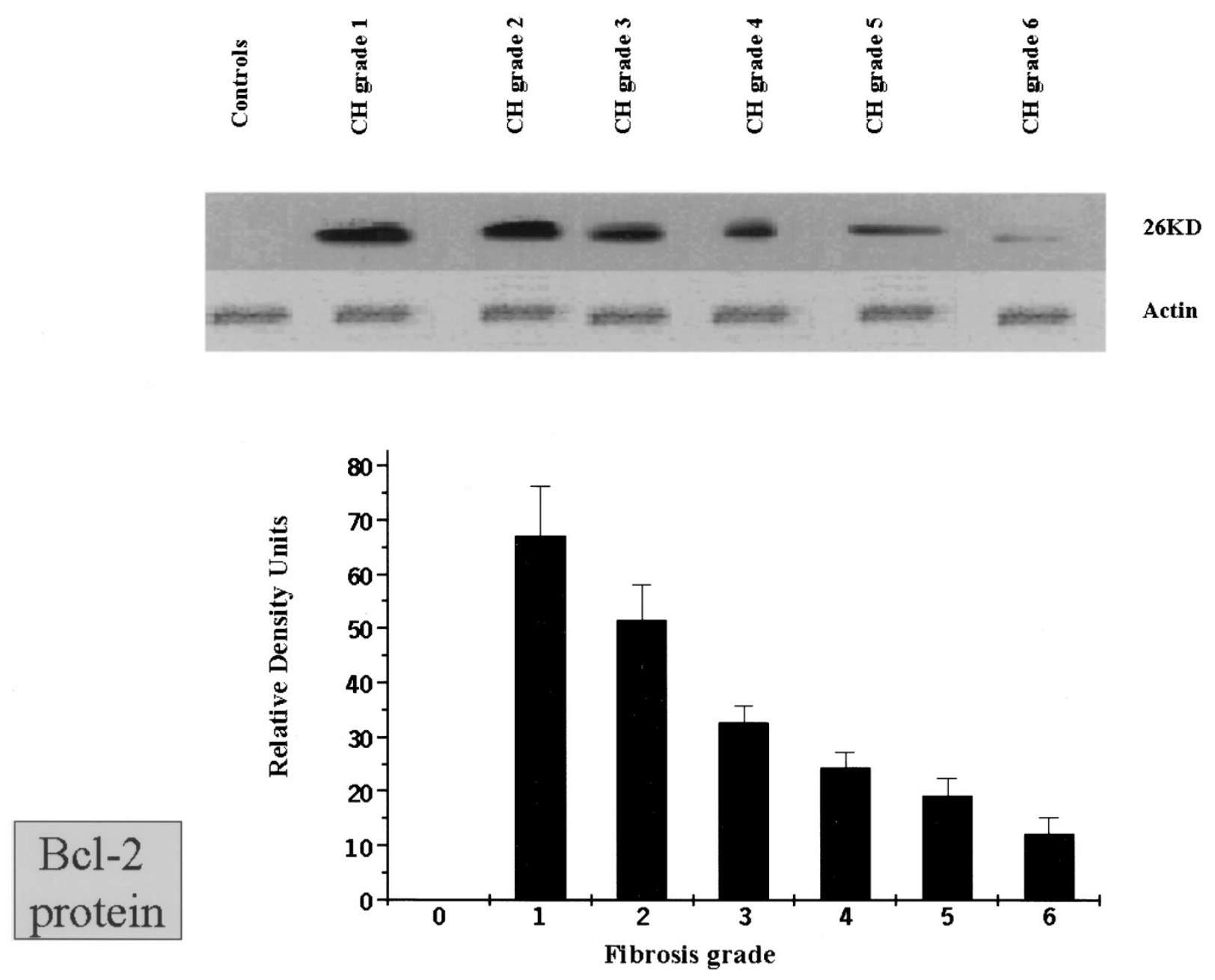

FIGURE 1. Western blot analysis for Bcl-2 protein in liver biopsies of group B (chronic hepatitis Grade 1-chronic hepatitis Grade 6) and in the control group (controls). Densitometry tracing was used to illustrate the quantitative differences (bottom of the figure). Fibrosis Grade 0 corresponds to the controls. The differences in the bcl-2 protein levels between fibrosis Grade 1 and Grade 6 were statistically significant $(P<.01)$.

\section{Double Staining Results}

As Table 5 shows, bcl-2 mRNA and bax protein were coexpressed as follows: in periportal hepatocytes, only in instances of $\mathrm{CH}$ with Fibrotic Stage 5 and 6 (11 HBV and $14 \mathrm{HCV}$ instances; Fig. 8A-B), and in cholangiolar epithelial cells of interface area and fibrous bands (Fig. 8A). Bax mRNA and bcl-2 protein was detected only in cholangiolar epithelial cells of interface area and fibrous bands. The same pattern was observed for the coexpression if bcl-2 protein/bax protein (Fig. 8C-D). TUNEL+ stain and simultaneous expression of bcl-2 protein was recorded in cholangiolar epithelial cells. TUNEL+ stain and simultaneous expression of bax protein was recorded in hepatocytes and in cholangiolar epithelial cells (Fig. 8E-F).

\section{DISCUSSION}

This study demonstrates that in patients with $\mathrm{CH}$ Type B or C, (1) the expression of apoptotic onco- genes bcl-2 or bax as detected by immunohistochemistry, ISH, and Western blotting analysis varied and depended on liver histology (inflammation grade and fibrosis) at the time of biopsy; (2) bcl-2 and bax are actively produced within hepatocytes and ductal or cholangiolar epithelial cells, but they display partially a different site of production and origin; (3) bcl-2 and bax expression are variably related to the degree of the impairment of liver function in human diseased liver; (4) there is a dose relation between the apoptotic process and the evolution and progression of human liver disease as expressed by the degree of inflammation and fibrosis; (5) the presence of apoptotic bodies (nuclei) in the liver parenchyma is reversibly and directly related to the severity of bcl-2 and bax protein expression, respectively; and (6) apoptosis seems to play a significant role during the early stages of chronic liver disease and fibrosis, whereas the expression of anti-apoptotic gene bcl-2 mRNA, from hepatocytes, in the late fibrotic stages implies that this oncogene 


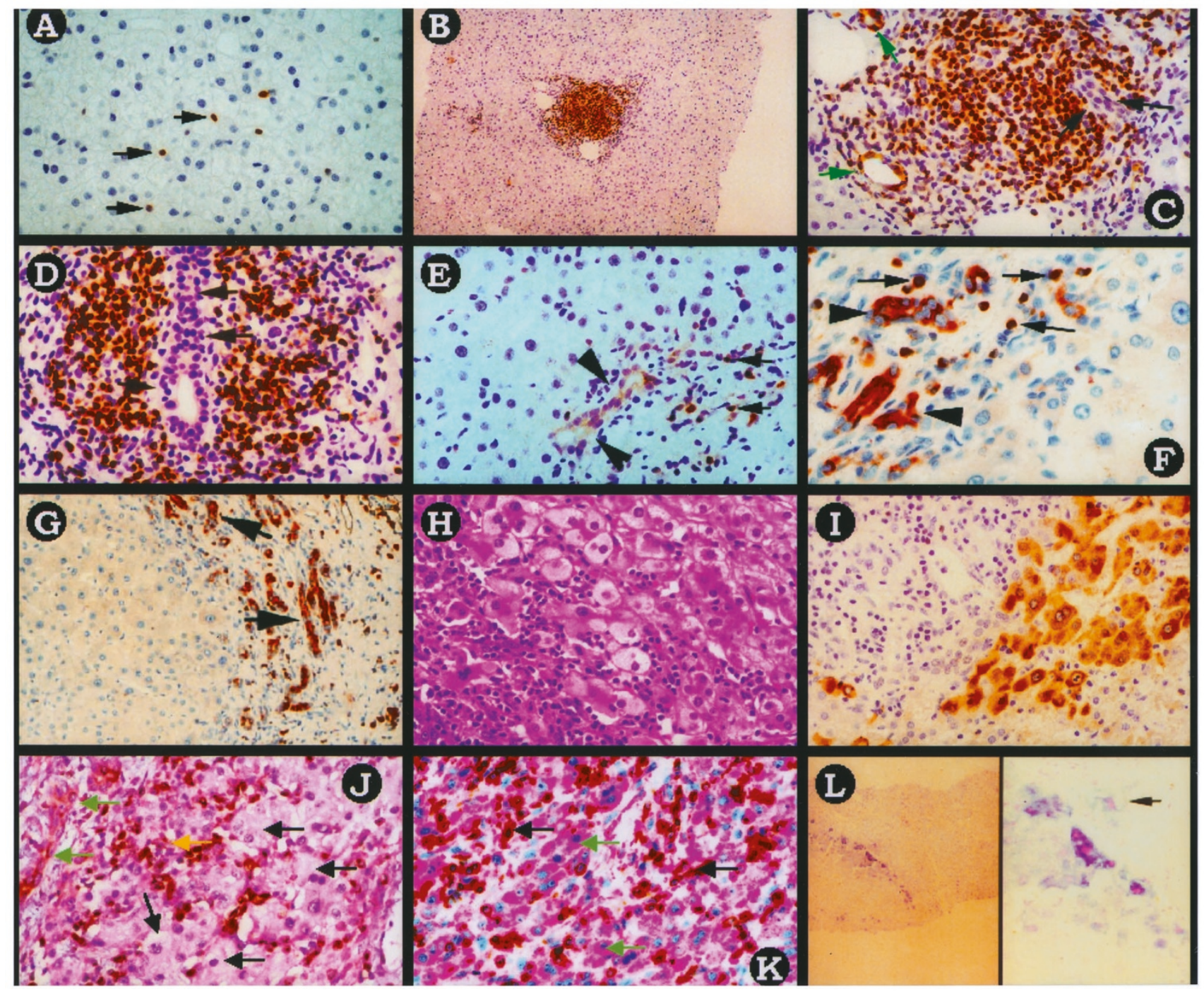

FIGURE 2. A, photomicrograph showing bcl-2 expression in intralobular lymphocytes (arrows). Note the negative stain in hepatocytes and Kupffer cells. 3,3'-Diaminobenzidine was used as chromogen and section was counterstained with Harris hematoxylin (streptavidin-biotin peroxidase; 400 $\times$ ). B-D, photomicrograph showing bcl-2 expression in a case of chronic hepatitis Type C. Note the positive stain of lymphocytes and cholangioles (C: green arrows) and the negative stain of epithelial cells of the interlobular bile duct (C and D: black arrows). 3,3'-Diaminobenzidine was used as chromogen, and the section was counterstained with Harris hematoxylin [streptavidin-biotin peroxidase $100 \times[\mathbf{B}]$ and $400 \times[\mathbf{C}$ and $\mathbf{D}])$. E, photomicrograph showing bcl-2 expression in a case of chronic hepatitis Type B. Note the positive stain of lymphocytes (thin arrows) and cholangioles (arrowheads) and the negative stain of hepatocytes. 3,3'-Diaminobenzidine was used as chromogen, and the section was counterstained with Harris hematoxylin (streptavidin-biotin peroxidase, 400×). F-G, photomicrographs showing bcl-2 expression in lymphocytes (arrows) and cholangioles (arrowheads) in the fibrous bands of a cirrhotic liver caused by hepatitis C. AEC was used as chromogen, and the section was counterstained with Harris hematoxylin (streptavidin-biotin peroxidase, $400 \times[\mathrm{F}]$ and $200 \times[\mathrm{G}]$ ). $\mathbf{H}$, photomicrograph from a case of chronic hepatitis B showing ground-glass cells (H\&E, 400×). I, photomicrograph from the same case showing HBS antigen expression. 3,3'-Diaminobenzidine was used as chromogen, and the section was counterstained with Harris hematoxylin (streptavidin-biotin peroxidase, 400×). J, photomicrograph from the same case showing bcl-2 protein expression in lymphocytes (brown stain, yellow arrow) and cholangiolar epithelial cells (green arrows). Note the ground-glass cells (black arrows). 3,3'-Diaminobenzidine was used as chromogen (H\&E and streptavidin biotin peroxidase, 400×). K, photomicrograph from the same case showing bcl-2 protein expression in lymphocytes (brown stain, black arrows) and HBS antigen expression within ground-glass cells (red stain, green arrows). 3,3'-Diaminobenzidine and Fast Red were used as chromogens, and the section was counterstained with Harris hematoxylin (streptavidin-biotin peroxidase and streptavidin-biotin alkaline phosphatase, $400 \times$ ). L, ISH histochemistry (digoxigenin) showing bcl-2 mRNA expression within hepatocytes near the edge of fibrous tissue and within a cholangiole (right arrow) in a cirrhotic liver with chronic hepatitis B. BCIP/NBIT was used as chromogen, and the section was counterstained with Nuclear Fast Red (ISH, 100× [left] and $400 \times$ [right]).

may be related to the presence of end-stage liver disease and the possible presence of hepatocellular carcinoma in cirrhotic livers because of chronic infection with hepatitis B or hepatitis C viruses. Figure 9 summarizes the findings of this study.

Bcl-2, a novel apoptotic inhibitor, is very important for the development and maturation of liver tissue, as bcl-2 deficiency manifests as excessive apoptosis during liver development $(3,5)$. In adult human liver, bcl-2 protein expression has been detected by immunohistochemistry $(6,8)$. In the current study, bcl-2 protein and mRNA were expressed in lymphocytes within portal tracts, the interface area, and lobules and bands of connective tissue. In 


\begin{tabular}{|c|c|c|c|c|}
\hline \multirow{2}{*}{ Distribution } & \multicolumn{2}{|c|}{ Bax Protein } & \multicolumn{2}{|c|}{ Bax mRNA } \\
\hline & Controls & $\mathrm{CH}$ & Controls & $\mathrm{CH}$ \\
\hline \multicolumn{5}{|l|}{ Portal tracts } \\
\hline Lymphocytes & NP & $0.41 \pm 0.05$ & NP & $0.44 \pm 0.1$ \\
\hline Interlobular ducts & $0.11 \pm 0.05^{\mathrm{a}}$ & $0.51 \pm 0.07^{\mathrm{a}}$ & $0.12 \pm 0.12^{\mathrm{e}}$ & $0.57 \pm 0.07^{\mathrm{e}}$ \\
\hline \multicolumn{5}{|l|}{ Interface area } \\
\hline Cholangioles & NP & $0.30 \pm 0.05$ & NP & $0.37 \pm 0.11$ \\
\hline Lymphocytes & $0.12 \pm 0.02^{\mathrm{b}}$ & $0.40 \pm 0.3^{\mathrm{b}}$ & $0.16 \pm 0.04^{\mathrm{f}}$ & $0.46 \pm 0.03^{\mathrm{f}}$ \\
\hline \multicolumn{5}{|l|}{ Lobules } \\
\hline Hepatocytes & $0.12 \pm 0.02^{\mathrm{c}}$ & $0.62 \pm 0.05^{\mathrm{c}}$ & $0.13 \pm 0.06^{\mathrm{g}}$ & $0.64 \pm 0.1^{g}$ \\
\hline Kupffer cells & 0 & 0 & 0 & 0 \\
\hline Lymphocytes & $0.11 \pm 0.01^{\mathrm{d}}$ & $0.39 \pm 0.03^{\mathrm{d}}$ & $0.12 \pm 0.03^{h}$ & $0.42 \pm 0.1^{\mathrm{h}}$ \\
\hline Fibrous bands & NP & & NP & \\
\hline Lymphocytes & & $0.32 \pm 0.1$ & & $0.33 \pm 0.02$ \\
\hline Cholangioles & & $0.28 \pm 0.07$ & & $0.31 \pm 0.3$ \\
\hline
\end{tabular}

Values are mean \pm SD. NP: not present, $\mathrm{CH}$ : chronic hepatitis.

Differences significant at $\mathrm{p}<0.01$ in data with matching letter $\mathrm{a}-\mathrm{h}$

\begin{tabular}{|c|c|c|c|c|c|c|}
\hline 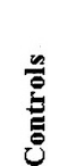 & 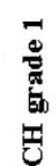 & 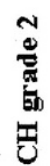 & 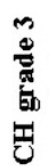 & 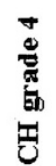 & 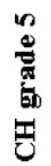 & 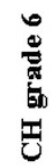 \\
\hline
\end{tabular}

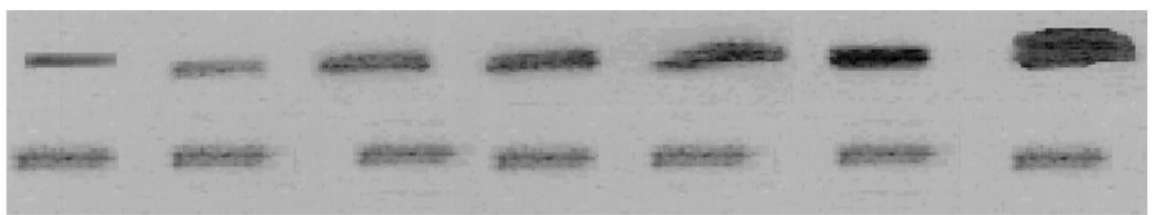

21KD

Actin
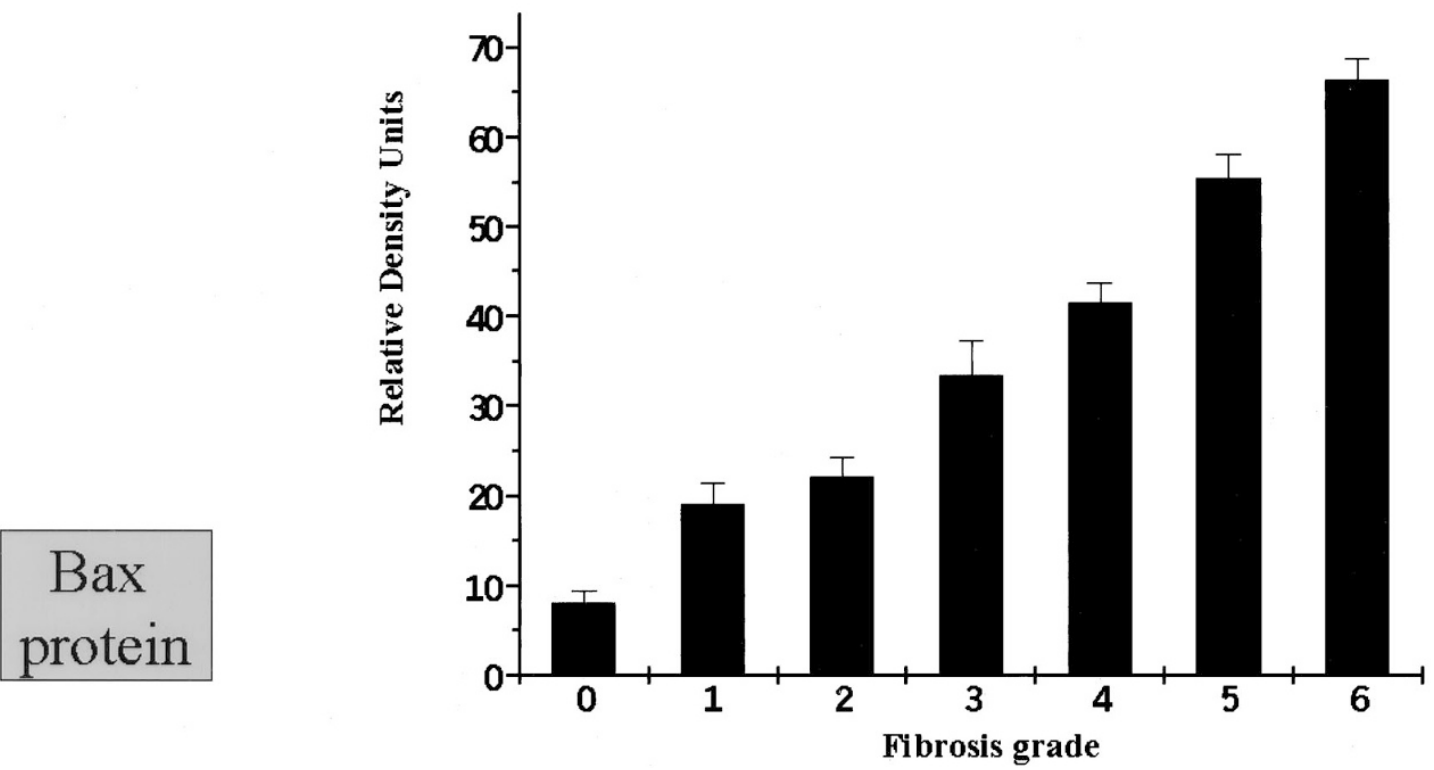

FIGURE 3. Western blot analysis for bax protein in liver biopsies of Group B (chronic hepatitis Grade 1 to chronic hepatitis Grade 6) and in the control group (controls). Densitometry tracing was used to illustrate the quantitative differences (bottom of the figure). Fibrosis grade 0 corresponds to the controls. The differences in the bax protein levels between the controls and $\mathrm{CH}$ cases from fibrosis Grade 1 to Grade 6 was statistically significant $(P<.01)$.

addition, they were detected within cholangiolar epithelial cells of the interface area and fibrous tissue. Hepatocytes, epithelial cells of the interlobular ducts, and Kupffer cells were negative for bcl-2 protein. We found also that bcl-2 was actively produced from hepatocytes (mRNA expression) in $\mathrm{CH}$ cases with incomplete or established cirrhosis, and more specifically, this oncogene production char- 


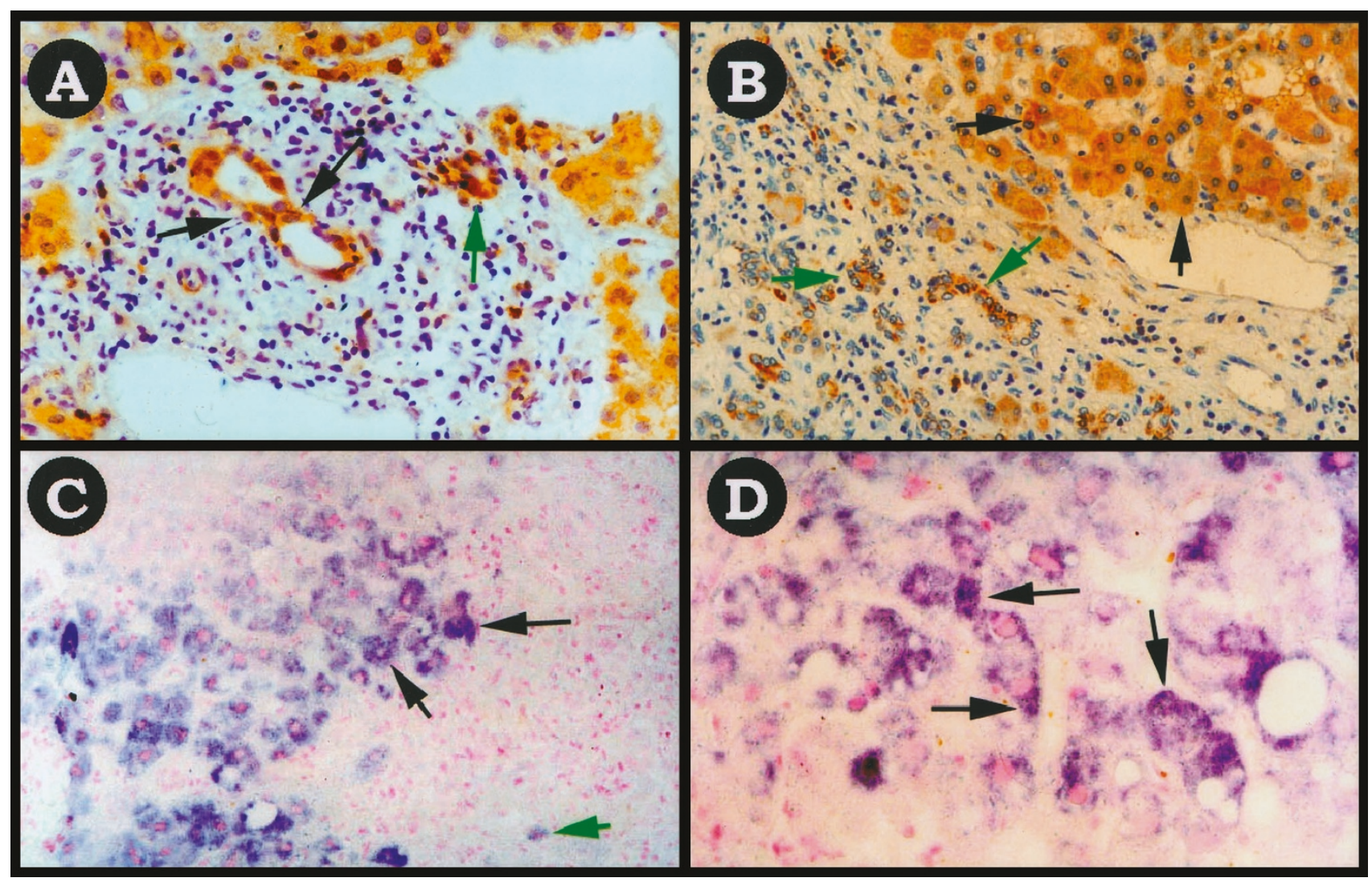

FIGURE 4. A, photomicrograph showing bax protein expression in epithelial cells of the interlobular duct (black arrows), in the cholangiolar epithelial cells (green arrow), and in lymphocytes of a portal tract in a case of chronic hepatitis Type B. 3,3'-Diaminobenzidine was used as chromogen, and the section was counterstained with Harris hematoxylin (streptavidin-biotin peroxidase, $400 \times$ ). B, photomicrograph showing bax expression in lymphocytes and cholangioles (green arrows) in the interface area and hepatocytes (black arrows) in a section from the same case shown in Figure 2F-G (cirrhotic liver caused by chronic hepatitis Type C). AEC was used as chromogen, and the section was counterstained with Harris hematoxylin (streptavidin-biotin peroxidase, $400 \times$ ). Compare the positive hepatocytic stain for bax protein with the negative one for bcl-2 protein in Figure 2F-G. C-D, ISH histochemistry (digoxigenin) showing bax mRNA expression within hepatocytes (C and D: black arrows) and within a cholangiole (C: green arrow) in a cirrhotic liver with chronic hepatitis C. BCIP/NBIT was used as chromogen, and the section was counterstained with Nuclear Fast Red (ISH, $200 \times[$ C] and $400 \times[$ D]).

acterized the liver cells that were located in Zone 1 (periportal area) or near the fibrous bands surrounding the regenerative nodules. In the past, Frommel et al. (7), using a standard immunohistochemical method, showed that bcl-2 protein was expressed in periportal hepatocytes in cases of cirrhosis caused by hepatitis C. In this study, and in a previous one (8), we could not demonstrate any bcl-2 protein positivity in hepatocytes. This difference could be attributed to the sensitivity of the immunohistochemical technique, although we used a well-controlled immunohistochemical method and the positive-control slides displayed strong cytoplasmic immunohistochemical staining for bcl-2.

It seems though, that the active production of bcl-2 (mRNA expression) in hepatocytes and its correlation with fibrotic stage (it was detected in cases of Stage $\geq 5$ ) implies that this oncogene is related to liver disease in advanced fibrotic stages. Elsewhere, we have shown that neoplastic hepatocytes in cases of hepatocellular carcinoma actively produce bcl-2 mRNA but do not express the bcl-2 protein (13). The striking difference observed between bcl-2 mRNA and protein expression in this study could be attributed to a disorder of posttranscriptional regulation of the bcl-2 gene. We speculate that a mechanism operating at the posttranscriptional level (for example, one associated with the 3' untranslated region) prevents this mRNA from being translated into protein in cases of incomplete or established cirrhosis.

The finding that bcl-2 mRNA was present in hepatocytes only in $\mathrm{CH}$ cases with Stage 5 or 6 , combined with the results of a previous study (7), implies that the presence of this oncogene may be correlated with the development of hepatocellular carcinoma that may accompany cases of cirrhosis, due to $\mathrm{CH}$ B or CH C. Down-regulation of the gene may play a role in liver cell differentiation and turnover by committing them to apoptosis, whereas abnormal expression of bcl-2 may lead to the accumulation of long-living cells and finally to tumor development. A deregulated expression of 
TABLE 4. Pattern of Apoptotic Bodies (nuclei) Expression in All 75 Liver Biopsies

\begin{tabular}{ccc}
\hline & \multicolumn{2}{c}{$\begin{array}{c}\text { Apoptotic cells (TUNEL }+ \\
\text { cells) }\end{array}$} \\
\cline { 2 - 3 } Distribution & Controls & $\mathrm{CH}$ \\
\hline Portal tracts & & $0.12 \pm 0.01$ \\
$\quad$ Lymphocytes & 0 & $0.15 \pm 0.03$ \\
$\quad$ Interlobular ducts & 0 & $0.23 \pm 0.05$ \\
Interface area & & $0.15 \pm 0.02$ \\
$\quad$ Cholangioles & $\mathrm{NP}$ & $0.25 \pm 0.06$ \\
Lymphocytes & $\mathrm{NP}$ & 0 \\
Lobules & & $0.19 \pm 0.01$ \\
Hepatocytes & 0 & $0.1 \pm 0.02$ \\
Kupffer cells & 0 & $0.22 \pm 0.3$ \\
Lymphocytes & $\mathrm{NP}$ & \\
Fibrous bands & $\mathrm{NP}$ & \\
Lymphocytes & & \\
Cholangioles & &
\end{tabular}

Values are mean $\pm \mathrm{SD}$.

NP: not present, $\mathrm{CH}$ : chronic hepatitis.

bcl-2 gene in neoplastic cells may transform them and increase their resistance to apoptosis. This hypothesis is further supported by the fact that bcl-2 provides a survival advantage to progenitor and effector cells in some tissues (11); thus, its expression in cholangiolar epithelial cells may be correlated with prolonged survival of these cells. Therefore, bcl-2 expression in the interface area may be an additional indication of the presence of liver stem cells (28), and especially of oval cells that represent a progeny of the hepatic cell compartment, which is constituted by the terminal ductule cells connecting the canals of Herring with the bile canaliculi and/or a distinct population of periductal cells (29). Elsewhere, we have demonstrated that in cases of $\mathrm{CH}$ Type $\mathrm{B}$ or $\mathrm{CH}$ Type $\mathrm{C}$, oval cell expression is related to the progress of fibrosis and coexistence of hepatocellular carcinoma (30). Thus, we are tempted to speculate that bcl-2 expression in the cholangioles may be related to the presence of liver progenitor cells that will differentiate to ductular epithelial cells and, finally, be related to the development of hepatocellular carcinoma. However, further research is warranted to confirm this possibility.

Regarding the role of bcl-2 in liver regeneration, Masson et al. (31) have shown that in cirrhotic rat

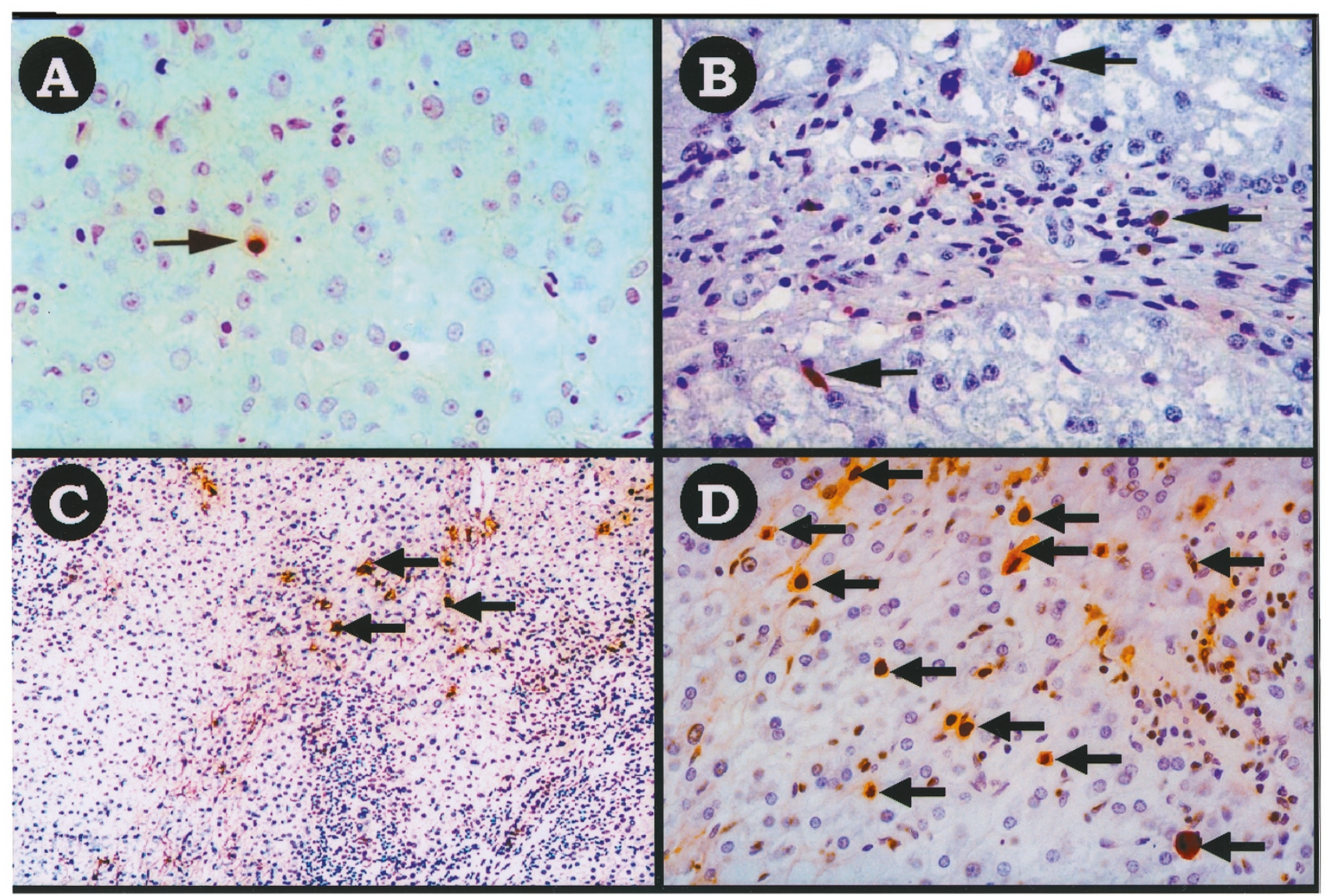

FIGURE 5. A, photomicrograph of ISH (TUNEL) showing an apoptotic body within a hepatocyte (arrow) in a case of chronic hepatitis C. 3,3'Diaminobenzidine was used as chromogen, and the section was counterstained with Harris hematoxylin (TUNEL peroxidase, 400 $\times$ ). B, photomicrograph of ISH (TUNEL) showing apoptotic bodies within hepatocytes (arrow in the top and the bottom of the figure) and in the fibrous tissue (arrow in the middle of the figure) in a case of chronic hepatitis B. 3,3'-Diaminobenzidine was used as chromogen, and the section was counterstained with Harris hematoxylin (TUNEL peroxidase, 400×). C-D, photomicrograph of ISH (TUNEL) showing numerous apoptotic bodies (black arrows) from a case of hepatitis $\mathrm{C}$ with an HAI category score of 3. 3,3'-Diaminobenzidine was used as chromogen, and the section was counterstained with Harris hematoxylin (TUNEL peroxidase, 100× [C] and 400× [D]). 


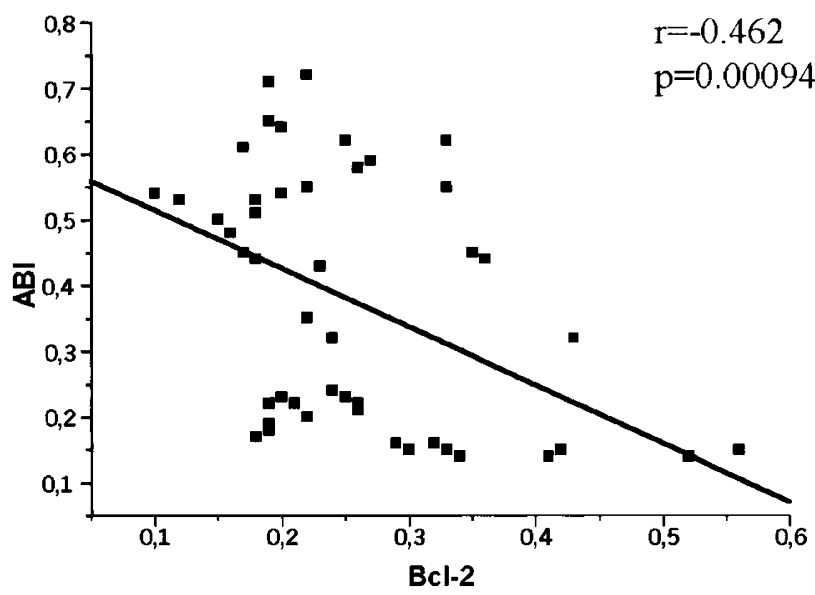

FIGURE 6. Reverse correlation between ABI and bcl-2 expression in cholangiolar epithelial cells in $\mathrm{CH}$ cases with fibrosis Stage 1-5 $(n=48)$.

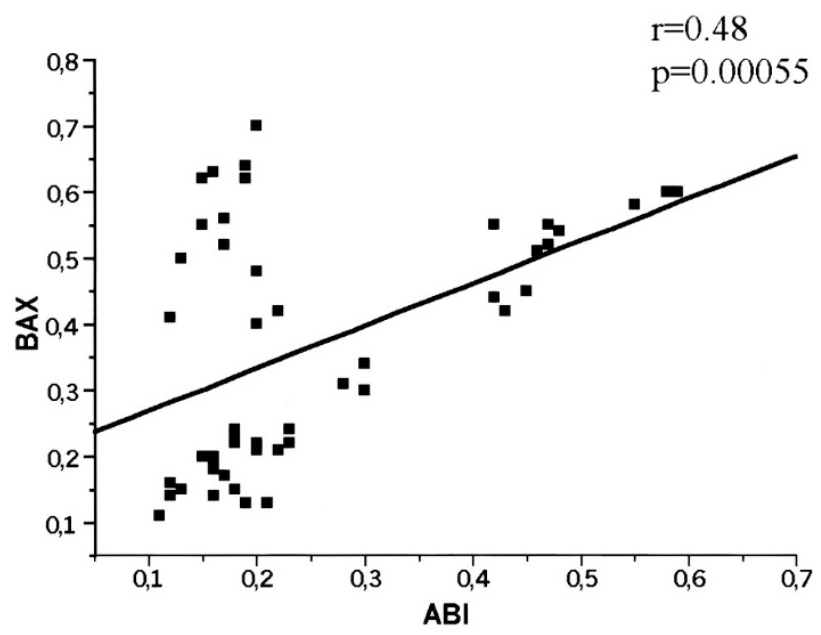

FIGURE 7. Direct correlation between ABI and bax expression in hepatocytes in $\mathrm{CH}$ cases with fibrosis Stage $1-5(n=48)$.

livers there is an early increase in bcl-2 mRNA levels after partial hepatectomy. These findings, combined with the increased bcl-2 expression in cholangioles of interface area, point again to the conclusion that impaired regeneration in the cirrhotic livers may be mediated though the activation of oval cells (alternative pathway of liver regenera- tion), which resist apoptosis and show a further differentiation to hepatocytes or ductal epithelial cells that will replace and colonize the damaged liver. In addition, the absence of bcl 2 expression in cholangiolar epithelial cells in cases of acute lobular hepatitis (8) implies that this oncogene is involved in the progress of liver disease only in the chronic phase.

In this study, bax protein expression in the control liver was similar to that described elsewhere $(16,17)$. Bax protein promotes apoptosis by enchanting cell susceptibility to apoptotic stimuli (14). The action of bax can be neutralized by its heterodimerization with bcl-2 and some other suppressors of cell death, such as bcl-x and mcl-1 (16). It was previously thought that when half or more of the endogenous bax was heterodimerized with either bcl-2 or bcl-x, apoptosis was repressed (17).

An interesting finding of the study was that bax protein was expressed in epithelial cells of interlobular ducts in portal tracts and also in cholangiolar epithelial cells of the interface area. The former did not express any bcl-2 (protein or mRNA), whereas the latter (cholangiolar cells) did show bcl-2 expression. Several nonmutual explanations could be given. Bax oncogene is an apoptotic promoter, and its presence in epithelial cells of interlobular ducts and hepatocytes implies that these cells are prone to apoptosis. In addition, bax presence in cholangiolar epithelial cells may suggest that this oncogene is related to cholangiolar absence through apoptosis, as has been shown elsewhere (20). However, the direct correlation of bax protein with the degree of liver fibrosis only for Stages 1-5 implies that bax plays a critical role only in the initial stages of liver fibrosis, and not when irreversible cirrhosis has been established. This expression is directly related to ABI indices. These results imply that tissue denudation via apoptosis through the initial stages of fibrosis leads to the absence of cellular elements at the end-stage liver diseases. Similar results have been observed in other tissues (32). Increased bax mRNA expression and apoptosis have also been reported in cirrhotic rats, in which

TABLE 5. Pattern of bcl-2/Bax and TUNEL/Bax Co-Expression in 65 Liver Biopsies with $\mathbf{C H}$

\begin{tabular}{|c|c|c|c|c|c|}
\hline Distribution & $\begin{array}{l}\text { Bcl-2mRNA/ } \\
\text { Bax protein* }\end{array}$ & $\begin{array}{l}\text { BaxmRNA/ } \\
\text { Bcl-2 protein }\end{array}$ & $\begin{array}{l}\text { Bcl-2 protein/ } \\
\text { Bax protein }\end{array}$ & $\begin{array}{l}\text { TUNEL/Bcl- } \\
2 \text { protein }\end{array}$ & $\begin{array}{l}\text { TUNEL/ } \\
\text { Bax protein }\end{array}$ \\
\hline \multicolumn{6}{|l|}{ Portal tracts } \\
\hline Interlobular ducts & - & - & - & - & $t^{\varepsilon}$ \\
\hline \multicolumn{6}{|l|}{ Interface area } \\
\hline Cholangioles & + & + & + & $++^{\varepsilon}$ & $+^{\varepsilon}$ \\
\hline \multicolumn{6}{|l|}{ Lobules } \\
\hline Hepatocytes & $+*$ & - & - & - & $t^{\varepsilon}$ \\
\hline Kupffer cells & - & - & - & - & - \\
\hline \multicolumn{6}{|l|}{ Fibrous bands } \\
\hline Cholangioles & + & + & + & $++^{\varepsilon}$ & $+^{\varepsilon}$ \\
\hline
\end{tabular}

+ : positive stain (both agents present), -: negative stain (protein absent). $¥$ Only in cases with fibrosis stage 5 and 6 (11 instances of HBV and 14 cases of HCV). ${ }^{\varepsilon}$ : cells that undergo apoptosis and co-express bcl-2 or bax protein). 


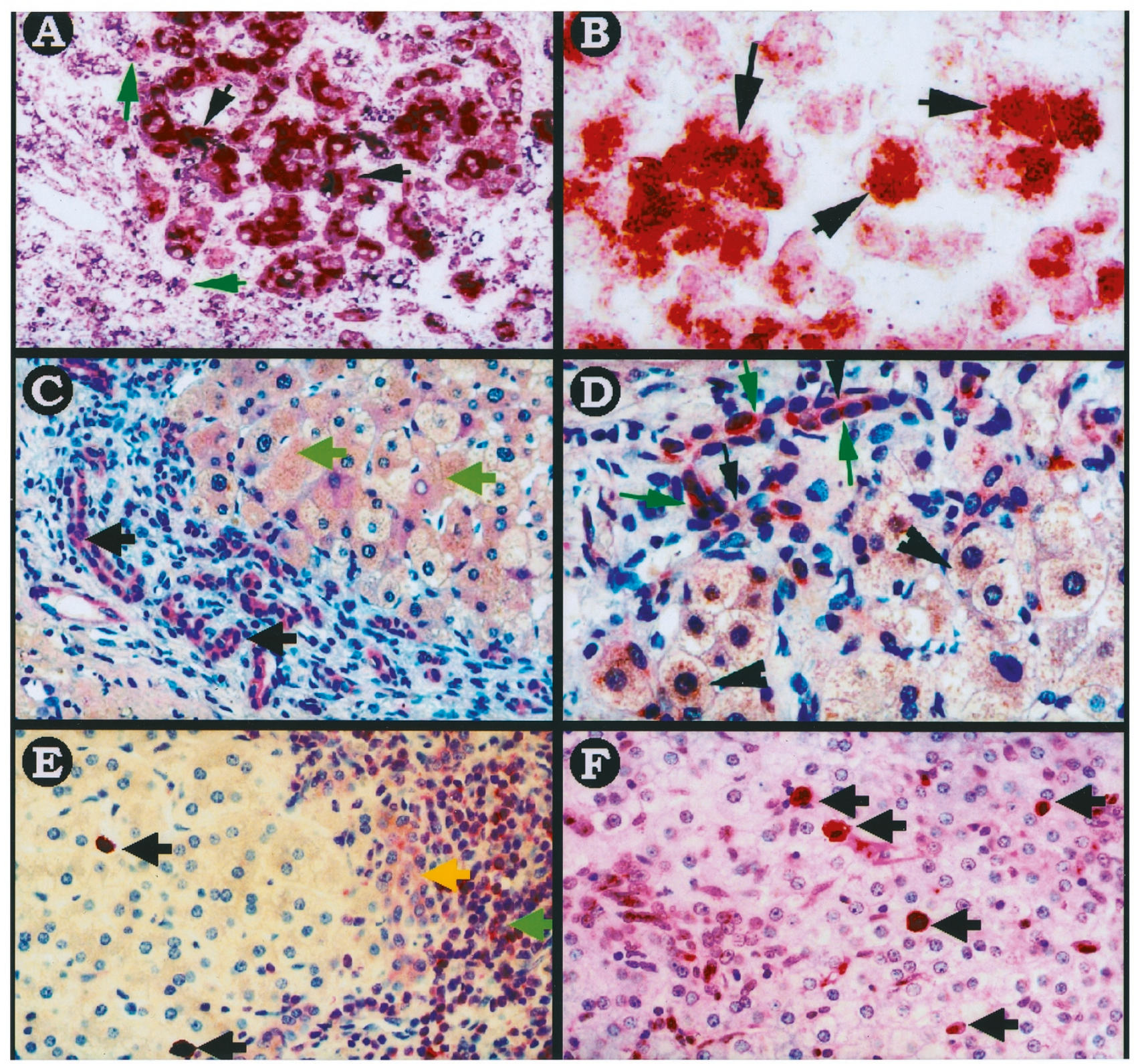

FIGURE 8. A-B double stain showing coexpression of bcl-2 mRNA and bax protein in hepatocytes (A and B: black arrows) and cholangioles (A: green arrows) in a cirrhotic liver caused by chronic hepatitis C. Chromogens used included the following: BCIP/NBIT (blue granular stain) for ISH (bcl-2 mRNA expression) and AEC (red stain) for immunohistochemistry (bax protein expression). No counterstain was used (ISH + streptavidinbiotin peroxidase, $200 \times[\mathrm{A}]$ and $400 \times[\mathrm{B}])$. C, double stain showing coexpression of bcl-2 and bax proteins in a cirrhotic liver with chronic hepatitis C. Hepatocytes express bax (brown stain, green arrows), whereas cholangioles in the fibrous band express bcl-2 (red stain, black arrows). Chromogens used included the following: 3,3'-diaminobenzidine (brown stain) and Fast red (red stain). Section was counterstained with Harris hematoxylin (streptavidin-biotin peroxidase and streptavidin-biotin alkaline phosphatase, $200 \times$ ). D, double stain showing coexpression of bcl-2 and bax proteins in a cirrhotic liver with chronic hepatitis C. Hepatocytes express bax (brown stain, arrowheads), whereas cholangioles in the fibrous band coexpress bax (brown stain, black arrows) and bcl-2 (red stain, green arrows). Chromogens used included the following: 3,3'-diaminobenzidine (brown stain) and Fast red (red stain). Section was counterstained with Harris hematoxylin (streptavidin-biotin peroxidase and streptavidin-biotin alkaline phosphatase, $400 \times$ ). E, double stain from a section of a cirrhotic liver caused by chronic hepatitis C. The photomicrograph shows apoptotic hepatocytes (TUNEL + cells: brown stain, black arrows) and bcl-2 protein expression within lymphocytes (red stain, green arrow) and cholangiolar epithelial cells (red stain, yellow arrow). Chromogens used included the following: 3,3'-diaminobenzidine (brown stain) and Fast Red (red stain). Section was counterstained slightly with Harris hematoxylin (streptavidin biotin peroxidase and streptavidin-biotin alkaline phosphatase, 400×). F, double stain from a section of a cirrhotic liver due to chronic hepatitis C. The photomicrograph shows apoptotic hepatocytes (TUNEL+ cells: brown stained nuclei) that coexpress bax protein (red-stained cytoplasm: black arrows). Chromogens used included the following: 3,3'-diaminobenzidine (brown stain) and Fast Red (red stain). Section was counterstained slightly with Harris hematoxylin (streptavidin biotin peroxidase and streptavidinbiotin alkaline phosphatase, $400 \times)$.

the decrease in antiapoptotic gene bcl-2 combined with a basal level of bax mRNA (apoptotic gene) is responsible for impaired regeneration(31).
The co-expression of bcl-2 mRNA and bax protein in periportal hepatocytes in $\mathrm{CH}$ cases with Stage $5-6$ is somehow a paradox. In the past, this 
A

Fibrosis stage $\begin{array}{llllll}2 & 3 & 4 & 5 & 6 \text { (cirrhosis) } \\ \text { †Bcl-2mRNA* }\end{array}$

Periportal

hepatocytes

Zone 1

Bax (mRNA/protein),

Apoptosis\$

\section{$\begin{array}{lllllll}\text { Fibrosis stage } & 1 & 2 & 3 & 4 & 5 & 6 \text { (cirrhosis) }\end{array}$}

Hepatocytes

No bcl-2 mRNA or protein expression

in zones 2 and 3

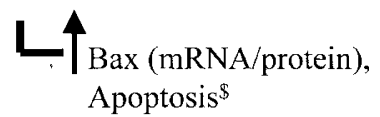

B

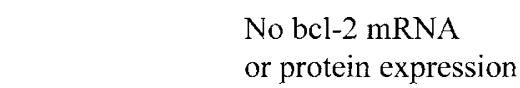

Interlobular

ducts

or protein expression

Bax protein and

TUNEL+ cells

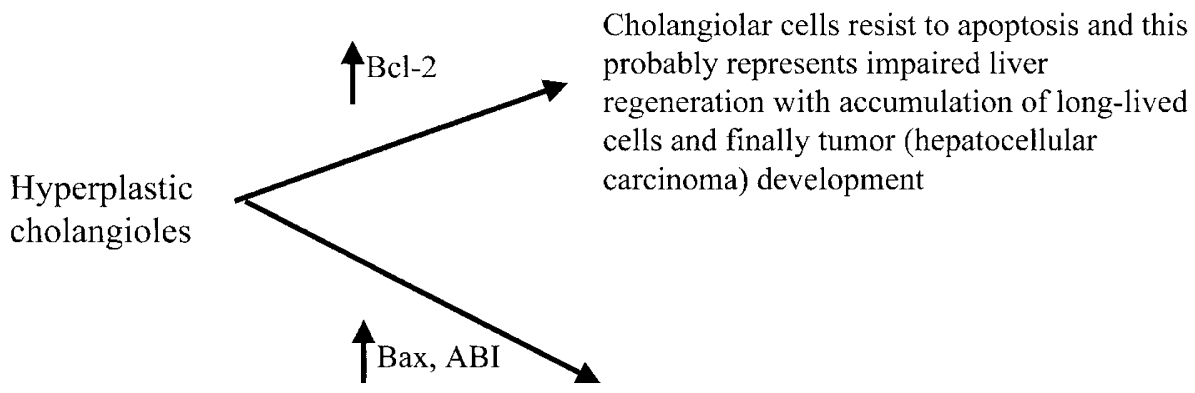

Depletion of cholangioles through apoptosis

FIGURE 9. Scheme summarizing the results of this study. A, bcl-2 and Bax expression and apoptosis in hepatocytes. *, bcl-2 mRNA expression in periportal hepatocytes only in cases with fibrosis Stage 5 and 6 implies that this oncogene is involved only in the late stages of liver disease and could be related to increased lifetime of those hepatocytes and tumor development. However, the expression of only Bcl-2 mRNA and not of the protein suggests posttranscriptional error. Similar findings have been observed in cases of hepatocellular carcinoma (see reference 13). ${ }^{\$}$, hepatocytic Bax expression and apoptosis are probably involved in hepatocytic growth regulation during infection. Their increase in Stages 1-5 reflects hepatocyte depletion through apoptosis and fibrous tissue accumulation until cirrhosis is established. B, bcl-2 and Bax expression and apoptosis in epithelial cells of interlobular ducts and hyperplastic cholangioles. ABI, apoptotic body index.

phenomenon has been described in cases of bile duct ligation (12), and it has been considered that bcl-2 expression reflects the resistance of liver cells to apoptosis and the toxic effect of bile during cholestasis, whereas bax expression in the same cells denotes an independent way of apoptosis. In this study, bax co-expression with bcl-2 probably does not reflect an adaptive down-regulation but a net increase in bax expression in hepatocytes during the progress of liver fibrosis.

Apoptosis and apoptosis-related proteins have been demonstrated to contribute in intrahepatic bile duct development $(3,5)$ and are involved in acute hepatitis and in $\mathrm{CH}$ (6-8). In this study, a 
significant reverse correlation of the severity of bcl-2 protein expression and direct correlation of bax expression with the presence of apoptotic bodies (nuclei) in the liver biopsies and with the degree of liver impairment was found. The latter is suggestive that apoptosis may play a role in the development and progression of liver disease. However, the presence of significant positive or negative correlation of ABI with bax and bcl-2 expression, respectively, in cases with Stages 1-5, but not with biopsies of Stage 6 (established cirrhosis), suggests that apoptotic process is important in liver fibrosis progress in the initial stages and not when cirrhosis has been established. In summary, this study shows that in cases of chronic HBV or HCV infection, bax may be involved in the hepatocyte cycle regulation during infection, whereas its expression in intraportal bile duct epithelium implies that this protein enhances susceptibility of these particular cells to apoptosis. The increased bax expression and ABI in fibrosis Stages 1-5 imply that they are responsible for hepatocyte depletion through apoptosis, during progress of liver fibrosis and fibrous tissue accumulation, until cirrhosis is established. Bcl-2 mRNA expression in periportal hepatocytes only in Stages 5 and 6 suggests that this oncogene is involved in the late stages of progressive liver fibrosis and failure and suggests furthermore that periportal hepatocytes are resistant to apoptosis. Bcl-2 expression in cholangioles of interface area suggests that this oncoprotein may be involved in growth regulation of these epithelial cells. It is certain that further research is required to clarify the exact role of apoptosis and apoptosis regulation genes, as well as of other factors involved in the overall liver scarring process. This may open new avenues in the management of human liver disease to prevent the progression to chronic liver failure.

\section{REFERENCES}

1. Cummings MC, Winterford CM, Walker NI. Apoptosis. Am J Surg Pathol 1997;21:88-101.

2. Kerr JF, Winterford CM, Harmon BV. Apoptosis. Its significance in cancer and cancer therapy. Cancer 1994;73:201326.

3. Columbano A, Ledda-Columbano GM, Coni PP, Faa G, Liguori C, Santa Cruz G, et al. Occurrence of cell death (apoptosis) during the involution of liver hyperplasia. Lab Invest 1985;52:670-5.

4. Patel T, Gores GJ. Apoptosis and hepatobiliary disease. Hepatology 1995;21:1725-41.

5. Terada T, Nakanuma Y. Detection of apoptosis and expression of apoptosis-related proteins during human intrahepatic bile-duct development. Am J Pathol 1995;146:67-74.

6. Charlotte F, L'Hermine A, Martin N, Geleyn Y, Nollet M, Gaulard P, et al. Immunohistochemical detection of bcl-2 protein in normal and pathologic human liver. Am J Pathol 1994;144:460-5.

7. Frommel TO, Yong S, Zarling EJ. Immunohistochemical evaluation of Bcl-2 gene family expression in liver of hepa- titis $\mathrm{C}$ and cirrhotic patients: a novel mechanism to explain the high incidence of hepatocarcinoma in cirrhotics. Am J Gastroenterology 1999;94:178-82.

8. Tsamandas AC, Thomopoulos K, Gogos C, Tepetes K, Kourelis T, Ravazoula P, et al. Expression of bcl-2 oncoprotein in cases of acute and chronic viral hepatitis type B and type C. A clinicopathologic study. Dig Dis Sci 2002;47:1618-24.

9. Cleary ML, Sklar J. Nucleotide sequence of a t(14;18) chromosomal breakpoint in follicular lymphoma and demonstration of a breakpoint-cluster region near a transcriptionally active locus on chromosome 18. Proc Natl Acad Sci U S A 1985;82:7439-43.

10. Reed JC. Bcl-2 and the regulation of programmed cell death. J Cell Biol 1994;124:1-6.

11. Hockenbery DM, Zutter M, Hickey W, Nahm M, Korsmeyer SJ. Bcl-2 protein is topographically restricted in tissues characterized by apoptotic cell death. Proc Natl Acad Sci U S A 1991;88:6961-5.

12. Kurosawa H, Que FG, Roberts LR, Fesmier PJ, Gores GJ. Hepatocytes in the bile duct-ligated rat express Bcl-2. Am J Physiol 1997;272:G1587-93.

13. Ravazoula P, Tsamandas AC, Kardamakis D, Gogos C, Karatza C, Thomopoulos K, et al. The potential role of bcl-2 mRNA and protein expression in hepatocellular carcinomas. Anticancer Res 2002;22:1799-805.

14. Oltvai Z, Milliman C, Korsmeyer SJ. Bcl-2 heterodimerizes in vivo with a conversed homolog, Bax, that accelerates programmed cell death. Cell 1993;74:609-19.

15. Yang E, Korsmeyer S. Molecular thanatopics: a discourse on the BCL2 family and cell death. Blood 1996;88:386-401.

16. Krajewski S, Krajewska M, Shabaik A, Miyashita T, Wang HG, Reed JC. Immunohistochemical determination of in vivo distribution of bax, a dominant inhibitor of bcl-2. Am J Pathol 1994;145:1323-36.

17. Penault-Llorca, Bouabdallah R, Devilard E, Charton-Bain MC, Hassoun J, Birg F, et al. Analysis of bax expression in human tissues using the anti-bax 4F11 monoclonal antibody on paraffin sections. Pathol Res Pract 1998;194:457-64.

18. Salakou S, Tsamandas AC, Bonikos DS, Papapetropoulos T, Dougenis D. The potential role of bcl-2, bax and Ki67 expression in thymus of patients with myasthenia gravis, and their correlation with clinicopathologic parameters. Eur J Cardiothorac Surg 2001;20:712-21.

19. Scopa C, Vagianos C, Kardamakis D, Kourelis T, Kalofonos HP, Tsamandas AC. Bcl-2/bax ratio as a predictive marker for therapeutic response to radiotherapy in patients with rectal cancer. Appl Immunohistochem Mol Morphol 2001;9: 329-34.

20. Stahelin BJ, Marti U, Zimmerman H, Reichen J. The interaction of Bcl-2 and Bax regulates apoptosis in biliary epithelial cells of rats with obstructive jaundice. Virchows Arch 1999; 434:333-9.

21. Lee RG. Chronic hepatitis. In: Lee RG, editor. Diagnostic liver pathology. 1st ed. St. Louis, MO: Mosby; 1994. p. 57-79.

22. Ishak K, Baptista A, Bianchi L, Callea F, De Groote J, Gudat $\mathrm{F}$, et al. Histological grading and staging of chronic hepatitis. J Hepatol 1995;22:696-9.

23. Giannopoulou E, Katsoris P, Hatziapostolou M, Kardamakis D, Kotsaki E, Polytarchou C, et al. X-rays modulate extracellular matrix in vivo. Int J Cancer 2001;94:690-8.

24. Bradford MM. A rapid and sensitive method for the quantitation of microgram quantities of protein utilizing the principle of protein-dye binding. Anal Biochem 1976;72:248-54.

25. Vis AN, Kranse R, Nigg AL, van der Kwast TH. Quantitative analysis of the decay of immunoreactivity in stored prostate needle biopsy sections. Am J Clin Pathol 2000;113:369-73.

26. Hatanaka Y, Hashizume K, Kamihara Y, Itoh H, Tsuda H, Osamura RY, et al. Quantitative immunohistochemical eval- 
uation of HER2/neu expression with HercepTest in breast carcinoma by image analysis. Pathol Int 2001;51:33-6.

27. Harada K, Iwata M, Kono N, Koda W, Shimonishi T, Nakanuma Y. Distribution of apoptotic cells and expression of apoptosis related proteins along the intrahepatic biliary tree in normal and non-biliary diseased liver. Histopathology 200;37:347-54.

28. Hsia CC, Evarts RP, Nakatsukasa H, Marsden ER, Thorgeirsson SS. Occurrence of oval-type cells in hepatitis B-virus associated human hepatocarcinogenesis. Hepatology 1992; 16:1327-33.

29. Petersen BE, Zajac VF, Michalopoulos GK. Hepatic oval cell activation in response to injury following chemically induced periportal or pericentral damage in rats. Hepatology 1998;27:1030-8.
30. Tsamandas AC, Gogos C, Kourelis T, Ravazoula P, Tepetes K, Petsas T, et al. Oval hepatocytes express alpha-fetoprotein and correlate with disease severity and presence of hepatocellular carcinoma in cases of chronic hepatitis type B or C. Hepatology 2001;34:392A.

31. Masson S, Scotte M, Garnier S, Francois A, Hiron M, Teniere $\mathrm{P}$, et al. Differential expression of apoptotic-associated genes post-hepatectomy in cirrhotic vs. normal rats. Apoptosis 2000;5:173-9.

32. Goumenos D, Tsamandas AC, El Nahas AM, Thomas G, Tsakas S, Sotsiou F, et al. Apoptosis and myofibroblast expression in human glomerular disease: a possible link with transforming growth factor-beta-1. Nephron 2002;92:28796. 